\title{
Supervision Practices as a Predictor of Maritime Accidents and Incidents in Territorial Waters, Mombasa County, Kenya
}

\author{
George Nyamoko Okong'o ${ }^{1 *} \quad$ Dr Daniel Mange Mbirithi ${ }^{2}$ \\ 1.Maritime security professional in the Executive Office of The President, former Director General Kenya \\ Maritime Authority and a Master of Arts (Public Policy and Administration) student, Kenyatta University. \\ P.O Box 85101-80100 Mombasa, Kenya \\ 2.Lecturer Department of Educational Management, Policy and Curriculum Studies, Kenyatta University \\ P.O Box 43844-00100 Nairobi, Kenya
}

\begin{abstract}
The study focused on supervision practices on maritime accidents and incidents in territorial waters, Mombasa County, Kenya. The study adopted a descriptive survey design. The objective of the study was to examine the influence of supervision practices on maritime accidents and incidents in territorial waters, Mombasa County, Kenya. The study population was 194 employees of Kenyan Ferry Services (KFS) who included 4 top management officers, 15 middle management and 175 supervisory officers. This study used stratified sampling to identify a sample size of 78 employees which represent $40 \%$ of the population. Primary data were collected through a questionnaire. Frequencies, descriptive and inferential statistics were derived to present the data. Demographic information was presented through charts; descriptive statistics presented using tables and bar graphs while inferential statistics, correlation analysis and regression were presented using tables. Analysis was done by Statistical Package for Social Sciences tool. A multiple linear regression model was used to test the significance. Findings revealed that $\mathrm{R}^{2}$ was $0.783, \beta=0.531, \mathrm{t}=8.970, \mathrm{p}=0.000<0.05$ ). Study hypotheses concluded that supervisory practices had a statistically significant influence on maritime incidents and accidents in territorial waters in Kenya. Study suggests solutions to curb maritime accidents and incidents in the Coast region. The study may be of importance to the government by using the recommendations to enact policies aimed at further minimizing accidents in Kenyan territorial and internal waters. The study findings may also benefit researchers who may wish to develop the study further through subsequent researches and also the academicians wishing to enrich their knowledge in the concept of supervision practices in curbing maritime accidents and incidents.
\end{abstract}

Keyswords:Supervision practices, maritime accidents and incidents, territorial waters

DOI: $10.7176 / \mathrm{PPAR} / 11-6-01$

Publication date:July $31^{\text {st }} 2021$

\subsection{INTRODUCTION}

Maritime is lifeblood of many economies that convey vast majority of trade and many vital resources; it can too be exploited by nations, criminals and terrorists hence calling for national and international policing and regulation. Safety has been considered as a critical component in all marine operations (Holling, 2016). An overview of the main international regulatory systems and conventions related to maritime safety management include Safety of Life At Sea (SOLAS), International Safety Management Code (ISMC), Maritime Labour Convection (MLC), Maritime Safety and Rescue (MASR) and International Maritime Satellite (INMARSAT), International Convection on Load Lines (LL) and Convection on the International Regulation for Preventing Collisions at Sea (COREG) among others. The maritime administrations' (flag and Coastal states) safety responsibilities are determined by the United Nations through the Convention on the United Nations Law of the Sea (UNCLOS). Although UNCLOS sets the broad regulative framework, the task of developing and maintaining workable regulations and supervision on ship safety within this framework is delegated to the International Maritime Organization (IMO), a UN agency which is responsible for international conventions and agreements (IMO, 2017).

In order to ensure best safety practices are adhered to, management needs salient information to support the process of decision-making. Sufficient and useful information is needed to identify possible problems in time, plan for actions required, give direction and allocate premises for the enforcement and supervision (Lin \& Wang, 2017). An efficient safety management system gives sufficient support for the operators to be aware of the state and variations of safety margins. Safety management system should be able to react to warning signals to change an adverse development of safety towards the desired direction. In its entirety, supervision is a complex concept in regard to dynamics, latent errors, human and organizational errors, claim for a vigilant, skillful and agile safety management system (Tenold, 2018).

To protect national interests, the UK efforts have developed maritime governance capacity and capabilities of states in areas of strategic maritime importance and protection of the UK, citizens and economy by supporting the safety and security of ports and offshore installations. The Australian Maritime Safety Authority (AMSA) is 
responsible for the supervision, audit, verification and certification of Australian vessels, for exercising control over foreign flag vessels in Australian ports (AMSA, 2009). Historically, the Chinese investigations of maritime casualties show approximately that $80 \%$ of all accidents are caused by substandard acts and $20 \%$ by substandard conditions, and that $80 \%$ of accidents are related to human acts, either direct or indirect, it is clear that the highest potential for improvement is on the human side, and that the development of a positive supervisory culture is a crucial way to improve the safety standards (Hetherington, Flin \& Mearns, 2006).

In Africa and East Africa region in particular, occurrence of marine accidents is common. The effects of accidents vary from minor injuries to fatalities and from insignificant damage to very severe damage to the environment and property (Peters, 2017). Safety at sea is a fundamental component that can be broken down into; institutions of legal regulations, implementing and overseeing safety measures and standards, legal instruments related to safety at sea and international maritime conventions (Galic, Lucik, \& Skoko, 2014). In Nigeria, the number of marine accidents increases with increase in the level of oil prospecting and other maritime transport activities along the Niger-Delta and Coastal regions (Bergantino \& Marlow, 2014). Malmo and Dalaklis (2017) documented that between 2000 and 2009, 552 persons died either as a result of ship and boat capsizing or collision in inland waters of Nigeria. Hence, an average fatality rate of about 55 deaths per year excluding vessel and cargo losses.

In Kenya, maritime accidents are most frequent during the rainy season when rivers swell up rendering sailing a challenge. Ironically, these incidences keep on occurring despite the fact that the Kenya Maritime Authority (KMA) Act 2006 that empowers the Agency to detain any ship that is considered to be unfit to sail due to defect on ship's hull, machinery or equipment or because of under-manning, overloading, unsafe or improper loading or general poor supervision. The high rate of maritime accidents and fatalities may be attributed to the high dependence on passenger vessels in Kenya. This fact is linked by various factors like; unsupervised operation of old and substandard vessels, vessel congestion, poor maintenance, and abrupt perilous weather changes. Kenya Maritime Authority was established with a mandate to regulate, coordinate and oversee maritime affairs in Kenya's navigable waters. The Authority has a role to coordinate the activities of the Kenya Ports Authority (KPA), the Kenya Navy and other relevant body engaged during maritime search and rescue operations. KFS was established to oversee operations of state owned ferries. In Kenya, ferry and boat operators consider their occupation less risky despite the fact that they are exposed to adverse sea state and weather conditions (KMA, 2017). Accidents involving passenger ferries are common in coastal and inland navigable waters especially when maritime safety regulations are not stringently followed and monitored (Onsongo, 2017). KFS and KMA are mandated to ensure passenger safety in the ferries, maintenance of these ferries, and sensitization to passengers on safety aspects involved in passenger ferries including safety of navigation, maritime search and rescue operations. Despite presence of these institutions, accidents have continually hit the Kenyan maritime space thus the gap on accidents and incidents in Kenya exists. Passenger vessels may have undetected design defects obtained either during their construction or through fair tear and wear. In addition, deployment of incompetent crew, the physical aging of vessels and non-adherence to maintenance schedules and refits are common with vessels operating in our territorial and inland waters and may contribute to accidents. Despite measures aimed at improving safety of navigation, shipping accidents, and particularly collisions, remain a major concern. The objective of the study was to examine the influence of supervision practices on maritime accidents and incidents in territorial waters, Mombasa County, Kenya.

\subsection{LITERATURE REVIEW}

In cases where a vessel is to be used for mainly commercial services like transporting goods and especially people, then these vessels have an inclination to ensure that they are licensed as opposed to rarely commercial boats like the artisanal fishing (The Merchant Shipping Act, 2009). This puts the users at greater risk as in instances where an event while at the waters occurs to them, they cannot be easily traced and the matter followed up effectively. The country has enormous potential for water - based tourism that remains largely unutilized due to the lack of knowledge on how to go about getting the requisite supervision, licenses and working on a safe environment (Coast Development Authority, 2005). Indications from previous accident experiences point out to various factors that highly contribute towards their occurrence which include inadequate supervision, poor maintenance and incompetent crew capacity for on-board emergency response during distress emergencies and therefore contributing to a high number of causalities. Hamand (2017) identified in their research repeated causes in ferry casualties as inadequate maintenance and vessel design, overloading, human error, poor communication, bad weather and unavailable or delayed rescue response. Poor policies have been stipulated thus compromising passenger vessel safety. Also, the manner in which the whole operation is carried out, both by parties involved directly and otherwise, does not guarantee passenger vessel safety. Buzancic and Parunov (2016) conducted a review of statistical data on ship accidents and found out that supervising ship activities at sea is one of the main concerns of all the parties involved with maritime industries - ship designers, shipbuilders and ship owners, and all of them want to avoid serious outcomes of ship accidents leading to the enormous penalties, in 
terms of lives lost, damage to the environment and to cargo. Therefore, last 40 years more attention was given to the ship design and building activities, to the operation of the ships and the supervision of the ship operators and seafarers.

Metalden and Upnes (2017) indicated that advancements in information and communications technologies (ICT) create wider opportunities for improving performance of maritime and all other mode of transport. Such possibilities are found in construction and extending the capabilities of intelligent transport systems. Due to the specific and mostly international character of sea transport, the implemented solutions have to take account of the legal instruments in force. This means that new solutions require approval of each country concerned, consultations with neighboring states as well as, in many cases, approval of international bodies. The existing solutions, comprising such systems as Automatic Identification System, Vessel Traffic Services, Vessel Traffic Management Systems, Vessel Traffic Management and Information Systems, Long Range Identification and Tracking system, Safe-Sea Net, recently executed Maritime Navigation and Information Services project, as well as the concepts of Motorways of the Sea, e-Navigation and e-Maritime show that there is a need for setting forth guidelines for and architecture of maritime intelligent transport systems.

A study was carried out by Eide (2007) on intelligent ship traffic monitoring for oil spill prevention. The study described a model, which estimated the risk levels of individual crude oil tankers. The intended use of the model, which was ready for trial implementation at The Norwegian Coastal Administrations new Vardo VTS (Vessel Traffic Service) center, was to facilitate the comparison of ships and to support a risk based decision on which ships to focus attention on. For a VTS operator, tasked with monitoring hundreds of ships, this was a valuable decision support tool. The model answers the question, "Which ships are likely to produce an oil spill accident, how much is it likely to spill and to what extent?" The study offered a supervisory/monitory approach to track the performance of ships and to be able to assess the risk of accident occurrence. In the ability to predict the probability of risk occurrence, there is certainty of developing a way to prevent the problem or avoid the course of action if it is unavoidable. A study by Idiri (2012) analyzed the automatic identification system of maritime accident risk using rule-based reasoning. The research work proposed a system for the automatic identification of maritime accident risk. The system consisted of two modules. The first automates expert knowledge acquisition through the computerized exploration of historical maritime data, and the second provides a rule-based reasoning mechanism. According to the study, current maritime traffic monitoring systems were not sufficiently adapted to the identification of maritime accident risk. It was very difficult for operators responsible for monitoring traffic to identify which vessels were at risk among all the shipping traffic displayed on their screen. They were overwhelmed by huge amount of kinematic ship data to be decoded.

Pietrzykowski (2010) presented a concept of intelligent transport systems, developed since 1980s, includes all modes of transport. Relevant developments in road transport are the most advanced. Water transport, particularly maritime transport, has gained more attention in connection with building and further developments of maritime intelligent transport systems. Study by Balmat (2009) was carried out on Maritime Risk Assessment (MARISA). The study presented a fuzzy approach for (MARISA) applied to safety at sea. The aim was to define automatically an individual ship risk factor which could be used in a decision making system. To achieve this purpose, a modular and hierarchical structure using fuzzy logic was developed that allows for the obtaining of a fuzzy risk factor (FRF) composed of a static risk factor (SRF) and a dynamic risk factor (DRF). The static risk factor assessment took into account several static data relative to the ship (age, flag, gross tonnage, number of companies, duration of detention and type). The dynamic risk factor was evaluated by considering the meteorological conditions (sea state, wind speed and visibility) and the time of the day.

Kim et al. (2013) carried out a research on a case study of marine accident investigation and analysis with focus on human error and found out that nationally and internationally, reported statistics on marine accidents show that $80 \%$ or more of all marine accidents are caused fully or in part by human error. According to the statistics of marine accident causes from Korean Maritime Safety Tribunal (KMST), operating errors are implicated in $78.7 \%$ of all marine accidents that occurred from 2002 to 2006 . In the case of the collision related accidents, about $95 \%$ of them are caused by operating errors, and those human errors related collision accidents are mostly caused by failure of maintaining proper lookout and breach of the regulations for preventing collision. One way of reducing the probability of occurrence of the human error related marine accidents effectively was by proper supervision of operators and understanding the role of the human elements in accident causation. In research, causal factors cause, classification systems for marine accident investigation were reviewed and some typical human error analysis methods used in shipping industry were described in detail.

\subsection{Theoretical Framework}

The study was anchored on Domino theory coined by Herbert William Heinrich in 1929. The theory depicts accidents and incidents as the current troubles that an organization or a company encounters towards achieving its objectives/goals (Glaesel, 2008). Accidents happen while the employees behave unsafely or offer unsafe acts and the management ignores the presence on unsafe conditions. Therefore unsafe acts and unsafe conditions as 
the immediate (direct) causes of accidents are the central factors to cause an accident. Other physical and mental conditions of an employee as well as environmental forces and the lack of supervision on safety performance are the contributory causes of unsafe act and unsafe conditions leading to accidents.

The factor preceding the accident (the unsafe act or the mechanical or physical hazard) and it should receive the most attention. Heinrich felt that the person responsible at a company for loss control should be interested in all five factors, but be concerned primarily with accidents and the proximate causes of those accidents. Heinrich also emphasized that accidents, not injuries or property damage, should be the point of attack. In marine context under this theory, accidents are as result of mainly an unplanned and unanticipated events that strike while at sea. The theory proposes that work companies need to view accidents and incidents as the process throughout the company. It should be allocated resources just as other processes in the management decision making process in order to minimize its causation and impact on the marine sector.

\subsection{Conceptual Framework}

Independent variable

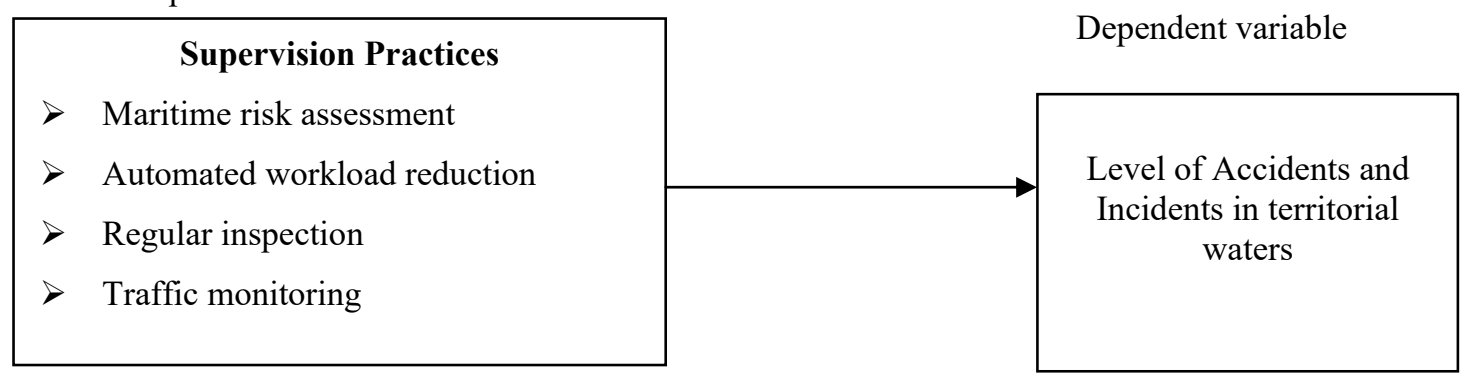

Source: Researcher, 2020

\subsection{RESEARCH METHODOLOGY}

The study adopted a descriptive survey design. The research study covered the top management, middle management and supervisory employees drawn from the Kenya Ferry Services (KFS) in Mombasa County and who have been working there for a minimum period of one year.

The targeted population consisted of 194 employees of KFS. The population of this study was top management, middle management and supervisory officers. This category of employees drawn from KFS is better placed to provide the required information. They are also entrusted to make decisions for the institution.

The sample size was a proportion of $40 \%$ of each stratum of the population. This is in line with Mugenda and Mugenda (2003) who suggested that $10 \%$ or more of a population is adequate for a study. Therefore, the sample size was 78 employees of KFS. The sample was selected using stratified random sampling. There are four top level managers at KFS and fifteen middle level managers. It was prudent to purposely include the total population of top and middle level managers in the study sample because they would provide comprehensive data across the KFS departments due to their vast experience in maritime operations. Sampling would otherwise disadvantage representation of some departments/sections. The largest population of employees concentrated at supervisory at 175 hence feasible to analyze a $34 \%$ sample which is adequate for the study.

Structured questionnaire was used in data collection of primary data on the basis of the information to be collected. The questionnaire was constructed in reference to the study variables hence makes it's the appropriate tool to capture the objectives of the study. It's also a suitable tool to correct cross section data at one point in time. The questionnaire contained both closed and open ended questions; open ended questions for detailed information and closed ended questions on facts about variables. The questionnaire was structured using a 5 Likert scale.

Primary data were collected by questionnaires administered to the respondents physically since the research is covering a wide area. The information was collected from employees using self-administered questionnaires.

\subsection{Research Findings}

This section presents the analysis discussed based on thematic and sub-thematic areas of study objectives. Thematic areas are idealized as per study objective; To examine the influence of supervision practices on the level of maritime accidents and incidents in territorial waters, Mombasa County, Kenya. Both quantitative and qualitative approaches were applied in processing, analyzing, and interpretation of the data. To generate percentages, frequency distributions, and measures of central tendency, the SPSS tool was used to run analysis. In addition, tables were produced.

Out of 78 questionnaires administered to KFS officials, 61 were dully filled giving a response rate of $78.20 \%$. Out of 4 top managers reached out for interview, were all available and participated giving a response 
rate of $100 \%$ and therefore all these response were regarded as the responsive instrument for subsequent analysis. Out of 15 middle managers targeted, 13 participated in the study while out of 59 officers in supervisory level targeted, 44 were able to fully participate in the study. This was in line with the views of Cooper and Schiendler (2008) who posit that at 75\% and beyond response rate is sufficient for generalization of statistical analysis.

To ensure understandability of features of KFS employees category respondents that the researcher dealt with in the study, capturing of background information was necessary, particulary in relation to roles undertaken and qualification of respondents. The study sought information from the respondents on gender, age, academic qualification and work experience in marititme industry. These features are discussed in detail in the following sub-themes.

The demographic characteristics of the KFS employees that were considered by the study were; gender, age, level of education, and work experience. Distribution by gender was important to check capacity or whether particular categories of roles were inclined to a particular gender and to ascertain that the nature of strategies adopted was in tandem with the specific needs of respondents and that none of the two genders was given preferential consideration in the selection of the respondents. Distribution of respondents by age group was done to ascertain that employees in the sector were evenly distributed across age groups so as to allow the younger workers to get job experience from the experienced employees and enable a continuous flow especially for succession purposes. This also gives a clearer picture on whether the young or older employees are more prone to causing accidents and incidents so as to tailor make strategies. Distribution of respondents by level of education was considered important because level of education would ensure minimum education requirements for employability purposes, skills and avenue for further training and also the impact on usefulness of strategies designed for each level of workers. Number of years worked helped to analyze the type of training design and supervision needs and if the length of duration worked had any impact on accidents and incidents level. The responses of the employees are shown in Table 4.1

Table 4.1: Demographic characteristics of employees $(n=61)$

\begin{tabular}{lcc}
\hline Distribution by gender & $\mathbf{n}(\mathbf{f})$ frequency & (\%) Percentage \\
Male & 45 & 73.8 \\
Female & 16 & 26.2 \\
\hline Total & $\mathbf{6 1}$ & $\mathbf{1 0 0}$ \\
\hline Distribution of respondents by age (years) & & 6.56 \\
Below 25 & 4 & 45.90 \\
& 28 & 31.15 \\
$26-35$ & 19 & 14.75 \\
$36-45$ & 9 & 1.64 \\
$46-55$ & 1 & $\mathbf{1 0 0}$ \\
Over 55 years & $\mathbf{6 1}$ & 4.92 \\
\hline Total & & 45.90 \\
\hline Distribution of respondents by years of work & 3 & 32.79 \\
1-2 years & 28 & 16.39 \\
2 -5 years & 20 & $\mathbf{1 0 0}$ \\
6 -10 years & 10 & \\
More than 10 years & $\mathbf{6 1}$ & \\
\hline Total & & 54.10 \\
\hline Distribution of respondents by highest & & 14.75 \\
academic qualification & 33 & 4.92 \\
O Level & 9 & 26.23 \\
Degree & 3 & $\mathbf{1 0 0}$ \\
Post graduate & 16 & \\
Other (college) & $\mathbf{6 1}$ & \\
\hline Total & & \\
\hline
\end{tabular}




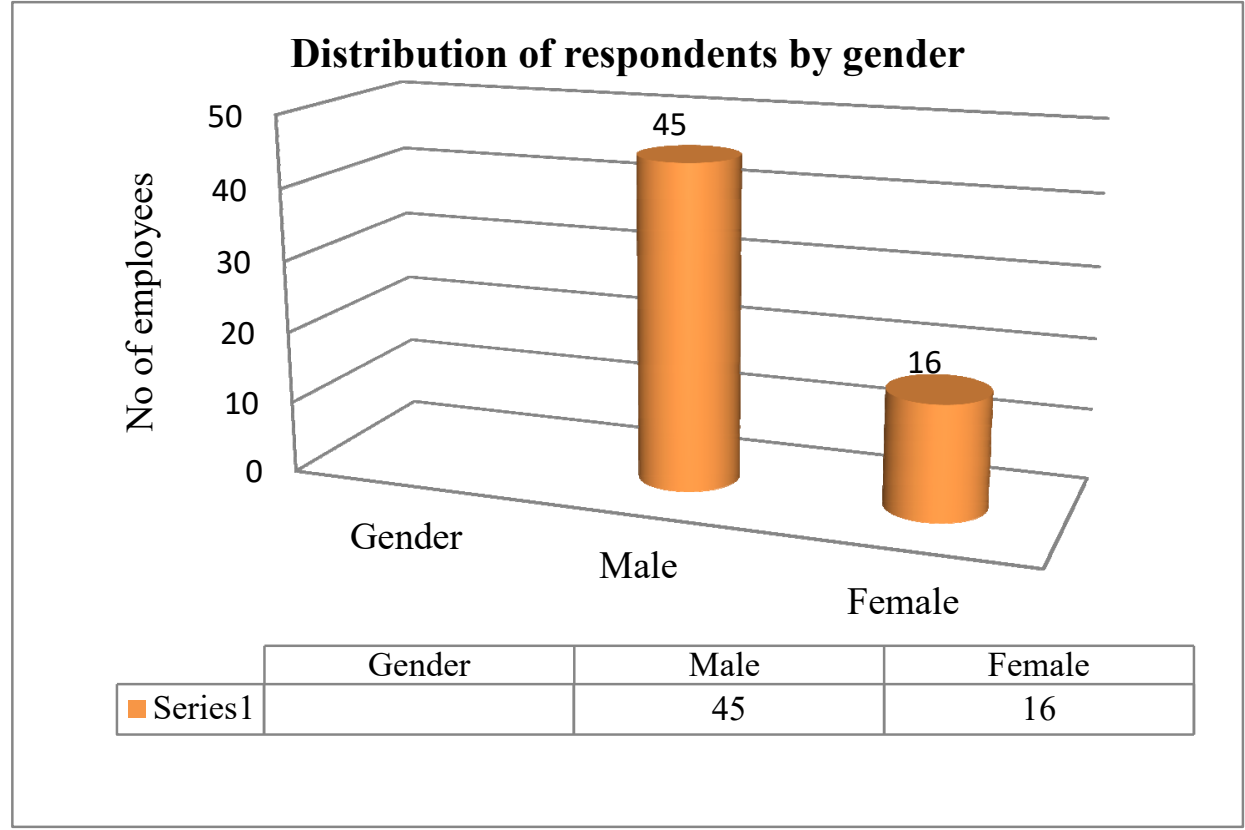

Figure 4.2: Distribution of respondents by gender

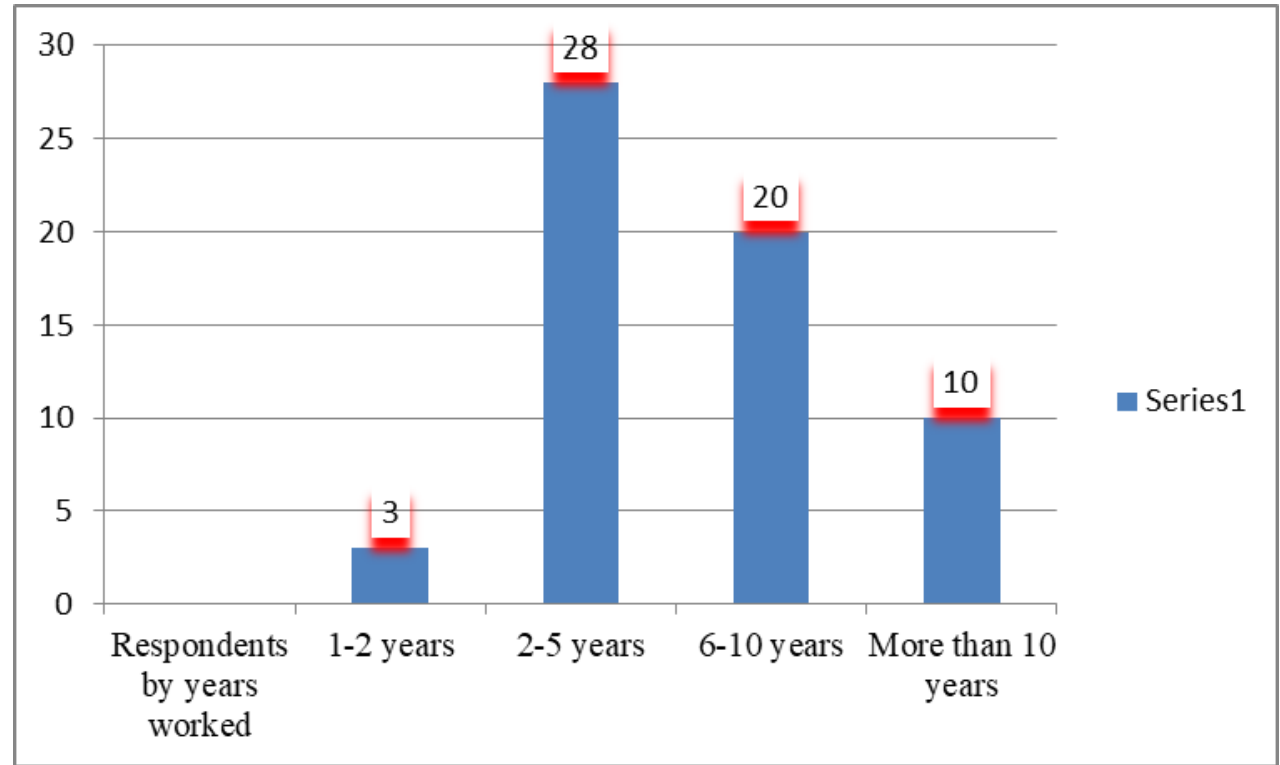

Figure 4.3: Distribution of respondents by years worked 


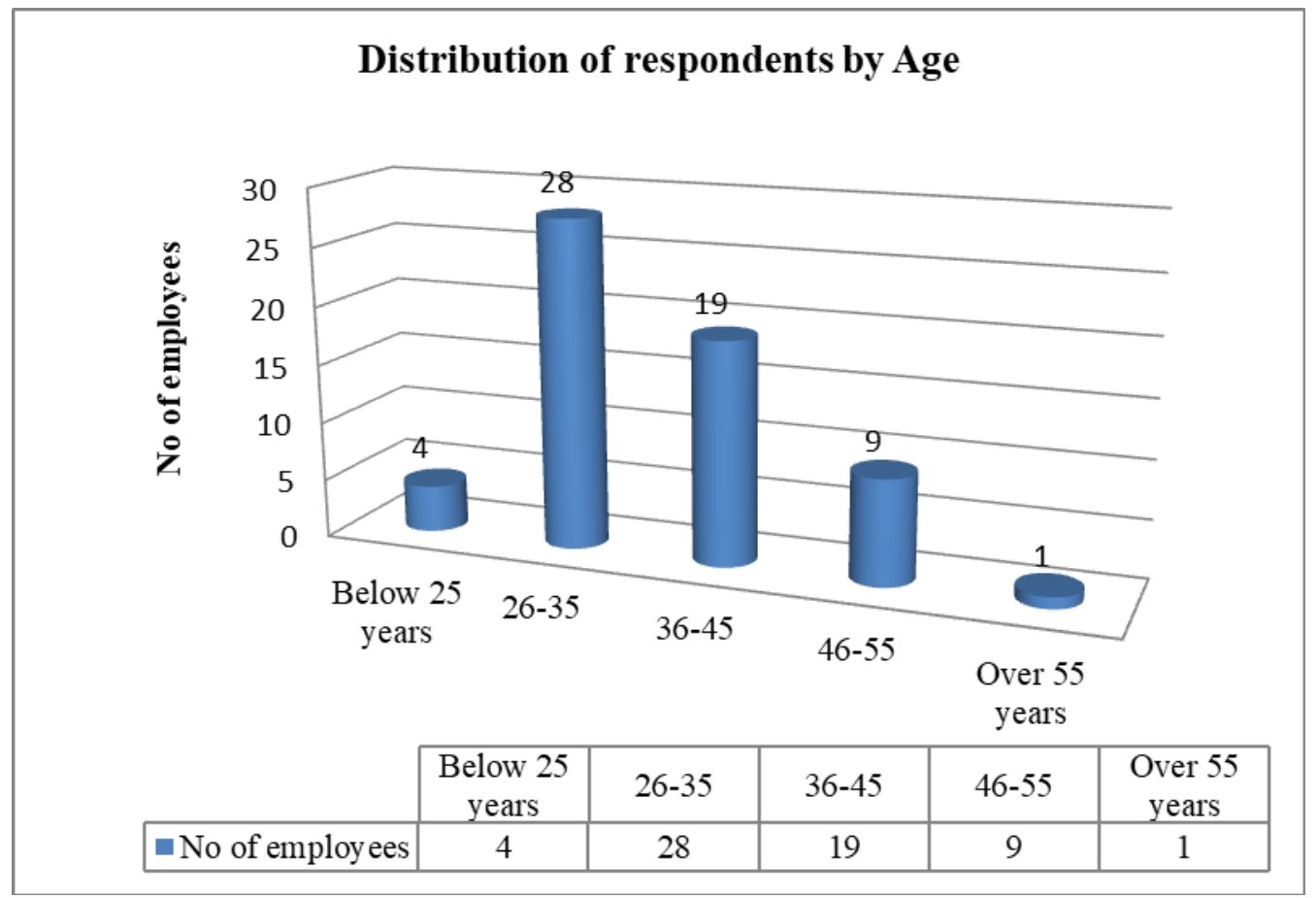

Figure 4.4: Distribution of respondents by age

\section{Distribution of respondents by academic qualification}

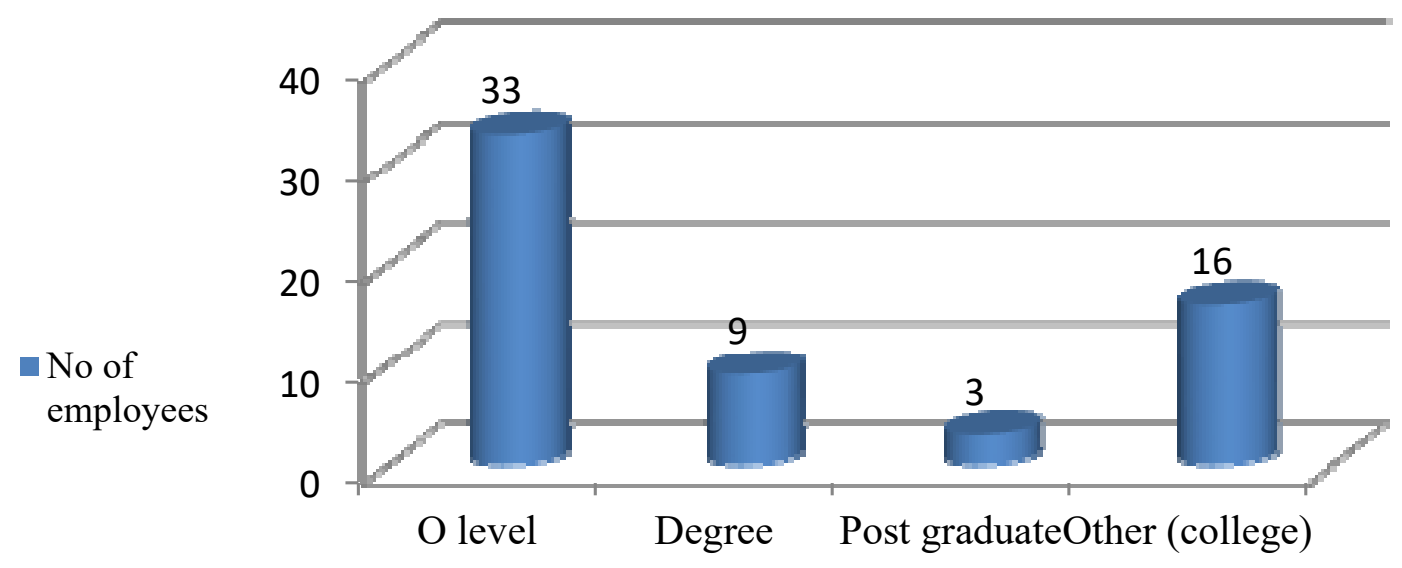

Figure 4.5: Distribution of respondents by academic qualification

4.4 Level of Maritime accidents and incidents in territorial waters

Level of maritime accidents and incidents in territorial waters was identified in the current study as the dependent variable. Respondents were given items rated on a five-point Likert scale ranging from strongly agree (SA); agree (A); moderately agree (MA); disagree (DA); strongly disagree (SDA) from which to choose relating to the variable. The findings were presented in Table 4.2 
Table 4.2: Means and standard deviations for Level of Maritime accidents and incidents in territorial waters

\begin{tabular}{|c|c|c|c|c|c|c|}
\hline Statement & $\begin{array}{l}\text { SDA } \\
\text { F (\%) }\end{array}$ & $\begin{array}{l}\text { DA } \\
\text { F }(\%)\end{array}$ & $\begin{array}{l}\text { MA } \\
\text { F (\%) }\end{array}$ & $\begin{array}{l}\text { A } \\
\text { F }(\%)\end{array}$ & $\begin{array}{l}\text { SA } \\
\text { Mean F } \\
(\%)\end{array}$ & $\begin{array}{l}\text { Std. } \\
\text { Deviation }\end{array}$ \\
\hline $\begin{array}{l}\text { Improvement on risk assessment of safety } \\
\text { facilities has reduced collision incidents }\end{array}$ & $\begin{array}{l}3 \\
(4.92)\end{array}$ & $\begin{array}{l}8 \\
(13.11)\end{array}$ & $\begin{array}{l}11 \\
(18.03)\end{array}$ & $\begin{array}{l}20 \\
(32.79)\end{array}$ & $\begin{array}{l}193.72 \\
(31.15)\end{array}$ & 1.242 \\
\hline $\begin{array}{l}\text { There is decrease in vessel stalling } \\
\text { incidences due to supervision of crew and } \\
\text { staff }\end{array}$ & $\begin{array}{l}2 \\
(3.28)\end{array}$ & $\begin{array}{l}4 \\
(6.56)\end{array}$ & $\begin{array}{l}7 \\
(11.48)\end{array}$ & $\begin{array}{l}30 \\
(49.18)\end{array}$ & $\begin{array}{l}18 \quad 3.95 \\
(29.50)\end{array}$ & 1.267 \\
\hline $\begin{array}{l}\text { Supervision and monitoring has led to } \\
\text { improved performance and safety of vessels }\end{array}$ & $\begin{array}{l}6 \\
(9.84)\end{array}$ & $\begin{array}{l}7 \\
(11.58)\end{array}$ & $\begin{array}{l}7 \\
(11.48)\end{array}$ & $\begin{array}{l}22 \\
(36.06)\end{array}$ & $\begin{array}{l}19 \quad 3.67 \\
(31.15)\end{array}$ & 1.089 \\
\hline $\begin{array}{l}\text { Supervision practices has led to timely } \\
\text { information for timely course of action, } \\
\text { therefore improving safety levels }\end{array}$ & $\begin{array}{l}8 \\
(13.11)\end{array}$ & $\begin{array}{l}8 \\
(13.11)\end{array}$ & $\begin{array}{l}8 \\
(13.11)\end{array}$ & $\begin{array}{l}14 \\
(22.95)\end{array}$ & $\begin{array}{ll}23 & 3.59 \\
(37.70)\end{array}$ & 1.108 \\
\hline $\begin{array}{l}\text { Management's continuous monitoring of } \\
\text { ferry operations has decreased the } \\
\text { probability of occurrence of accidents }\end{array}$ & $\begin{array}{l}9 \\
(14.75)\end{array}$ & $\begin{array}{l}12 \\
(19.67)\end{array}$ & $\begin{array}{l}4 \\
(6.56)\end{array}$ & $\begin{array}{l}14 \\
(22.95)\end{array}$ & $\begin{array}{l}22 \quad 3.46 \\
(36.07)\end{array}$ & 1.204 \\
\hline Composite scores & & & & & 3.68 & 1.219 \\
\hline
\end{tabular}

The research findings on Table 4.2 indicated that majority of the respondents agreed that the improvement on risk assessment of safety facilities has reduced collision incidents in the marine industry (63.94\%), while over $18.03 \%$ could not give a clear position regarding improvement in safety of facilities. This explains the continuous increase in marine accidents and incidents. Respondents agreeing that there is a decrease in vessel stalling incidences due to proper supervision of crew and staff $(78.68 \%)$, while small section of respondents were in disagreement $(9.84 \%)$. This therefore calls for continuous supervision and monitoring to enable employees to be well prepared to handle their responsibilities. Majority of the respondents agreed that supervision and monitoring has led to improved performance and safety of vessels has been satisfactorily addressed (67.21\%), while a significant number of respondents were in disagreement or agreed moderately. Regular supervision and monitoring of vessels should be a routine practice that would greatly improve safety of vessels, crew and other parties at sea. Majority of respondents further agreed that supervision practices has led to timely information for timely course of action, therefore improving safety levels $(60.65 \%)$ with significant response being moderate, however a minority were not satisfied. All employees should therefore be guided and encouraged on the importance of providing information on both positive and adverse occurrences and incidences while the management should assess and relay information on timely basis that would improve operations or prevent imminent danger, damage and accidents to vessels, marine environment and persons.

Almost a third of the respondents (34.42\%) disagreed that the management's continuous assessment of ferry activities decreases the probability of occurrence of accidents. This underscores the importance of having proper communication channels that allow free timely flow of information on vessels and operators. More than half of respondents $(59.02 \%)$ were in agreement confidence in management role on workforce that lead to reduction of accidents and incidents in territorial waters. Regarding the change in level of accidents and incidents in territorial waters, there were varied responses with a big group of respondents agreeing in almost all items. This implies that most practices put into place to address accidents and incidents had a positive impact although there are some issues that need to be addressed to enable facilities to deliver better safe services and safeguard human life.

The research findings in Table 4.2 showed that the mean score for the indicators used to measure level of accidents and incidents was 3.68 and standard deviation of 1.219. The study revealed majority agreement with the sentiment in each question item $\mathrm{M}(=3.68)$.

\subsection{Analysis of Means on Supervision Practices}

The respondents were requested to indicate the extent to which supervision practices influenced level of maritime accidents and incidents in territorial waters. They were given five items rated on a five-point rated as strongly agrees (5) to strongly disagree (1). A score of $\leq 1.5$ was interpreted to mean strongly disagree, while a score of 1.6 to $\leq 2.5$ implied that the respondents disagrees and 2.6 to $\leq 3.5$ was interpreted to mean that the respondent was neutral. A mean score of $3.6 \leq 4.5$ was interpreted to mean that respondents agree while a score of $\geq 4.6$ was interpreted to mean strongly agree. A standard deviation of $\leq 1$ was interpreted to mean that respondents had a consensus in the rating of the statement while a standard deviation greater than 1 was 
interpreted to mean that the respondents differed in their perception about the statement.

Table 4.3: Frequencies and Percentages, Means and Standard Deviations for Supervision Practices

\begin{tabular}{|c|c|c|c|c|c|c|}
\hline Statement & $\begin{array}{l}\text { SDA } \\
\text { F (\%) }\end{array}$ & $\begin{array}{l}\text { DA } \\
\text { F (\%) }\end{array}$ & $\begin{array}{l}\text { N } \\
\text { F (\%) } \\
\end{array}$ & $\begin{array}{l}\text { A } \\
\text { F (\%) }\end{array}$ & $\begin{array}{l}\text { SA Means } \\
\text { F }(\%) \\
\end{array}$ & $\begin{array}{c}\text { Std. } \\
\text { Deviation }\end{array}$ \\
\hline $\begin{array}{l}\text { The maritime industry conducts } \\
\text { continuous maritime risk assessment on } \\
\text { safety standards }\end{array}$ & $\begin{array}{l}10 \\
(16.39)\end{array}$ & $\begin{array}{l}18 \\
(29.51)\end{array}$ & $\begin{array}{l}8 \\
(13.11)\end{array}$ & $\begin{array}{l}17 \\
(27.87)\end{array}$ & $\begin{array}{ll}8 & 2.92 \\
(13.11) & \end{array}$ & 1.002 \\
\hline $\begin{array}{l}\text { Automation benefits operators of complex } \\
\text { systems in workload reduction and release } \\
\text { of resources for other onboard ship duties }\end{array}$ & $\begin{array}{l}9 \\
(14.75)\end{array}$ & $\begin{array}{l}19 \\
(31.15)\end{array}$ & $\begin{array}{l}14 \\
(22.95)\end{array}$ & $\begin{array}{l}8 \\
(13.11)\end{array}$ & $\begin{array}{ll}11 & 2.89 \\
(18.03) & \end{array}$ & 0.910 \\
\hline $\begin{array}{l}\text { Vessels are regularly inspected for } \\
\text { seaworthiness and safe operations }\end{array}$ & $\begin{array}{l}7 \\
(11.47)\end{array}$ & $\begin{array}{l}11 \\
(18.03)\end{array}$ & $\begin{array}{l}9 \\
(14.75)\end{array}$ & $\begin{array}{l}24 \\
(39.34)\end{array}$ & $\begin{array}{l}10 \quad 3.31 \\
(16.39)\end{array}$ & 1.114 \\
\hline $\begin{array}{l}\text { Maritime traffic monitoring systems are } \\
\text { adopted for timely identification of } \\
\text { maritime accident risk }\end{array}$ & $\begin{array}{l}12 \\
(19.67)\end{array}$ & $\begin{array}{l}16 \\
(26.23)\end{array}$ & $\begin{array}{l}9 \\
(14.75)\end{array}$ & $\begin{array}{l}13 \\
(21.31)\end{array}$ & $\begin{array}{l}112.91 \\
(18.03)\end{array}$ & 1.008 \\
\hline $\begin{array}{l}\text { The dynamic risk factor such as vessel } \\
\text { age, gross tonnage, duration of detention, } \\
\text { type and design are evaluated by } \\
\text { considering daily meteorological } \\
\text { conditions }\end{array}$ & $\begin{array}{l}10 \\
(16.39)\end{array}$ & $\begin{array}{l}19 \\
(31.15)\end{array}$ & $\begin{array}{l}8 \\
(13.11)\end{array}$ & $\begin{array}{l}16 \\
(26.23)\end{array}$ & $\begin{array}{lr}8 & 2.39 \\
(13.11)\end{array}$ & 0.967 \\
\hline Composite scores & & & & & 2.88 & 1.000 \\
\hline
\end{tabular}

The research findings on Table 4.3 indicated that slightly over half of the respondents disagreed that maritime industry conducts continuous maritime risk assessment on safety standards (59.01\%), while minority $(40.99 \%)$ gave a clear position regarding risk assessment. Respondents in disagreement that automation benefits operators of complex systems in terms of workload reduction and release of resources to perform other onboard ship duties stood at $(45.90 \%)$, with minority responses on agreement $(31.14 \%)$ while significant section of respondents were in of neither opinion and remained neutral on the matter (22.95\%). Majority of the respondents agreed that vessels are regularly checked and inspected for seaworthiness and safe operations (55.73\%), while a significant number of respondents were in disagreement or remained neutral. Majority of respondents further disagreed that maritime traffic monitoring systems have been sufficiently adopted for timely identification of maritime accident risk (45.90\%) with significant response being neutral, however minority were satisfied. Nearly half of the respondents $(47.53 \%)$ were not of the opinion that dynamic risk factor such as vessel age, gross tonnage, duration of detention, type and design are evaluated by considering daily meteorological conditions, while minority of respondents $(39.34 \%)$ were in agreement that dynamic risk factors were evaluated and considered each day.

The research findings in Table 4.3 showed that the mean score for the indicators used to measure supervision practices was 2.88 and standard deviation of 1.000. The study revealed majority agreement or disagreement with the sentiment in each question item $(\mathrm{M}=2.88)$. Based on individual questionnaires item responses, the results showed that to a great extent, respondents agreed that maritime industry conducts continuous maritime risk assessment on safety standards $(\mathrm{M}=2.92, \mathrm{SD}=1.002)$. Automation benefits operators of complex systems in terms of workload reduction and the release of resources to perform other onboard ship duties $(\mathrm{M}=2.89, \mathrm{SD}=0.910)$. Recording the highest mean, vessels are regularly checked and inspected for seaworthiness and safe operations $(\mathrm{M}=3.31, \mathrm{SD}=1.114)$. Maritime traffic monitoring systems have been sufficiently adopted for timely identification of maritime accident risk had mean and standard deviations of $(\mathrm{M}=2.91, \mathrm{SD}=1.008)$. Dynamic risk factor such as vessel age, gross tonnage, duration of detention, type and design are evaluated by considering daily meteorological conditions $(\mathrm{M}=2.39, \mathrm{SD}=0.967)$.

The overall mean and standard deviation $(\mathrm{M}=2.88, \mathrm{SD}=1.002)$, implied that the respondents had responses that were spread around the mean. They either agreed moderately or disagreed regarding the issues raised through the questionnaire, hence their responses concentrated around the mean. These research findings implied that supervision practices is a moderate factor in determining the level of maritime accidents and incidents.

Findings from this study agreed with Wolf et al., (2007). Study by Smith (2009), Akinyi (2009) and Abuyeka (2014) that well managed supervisory structure in maritime operations was directly attributed to efficient and safe operations. Findings were also in line with Theresa (2000) who argued that to a large extent, well-structured supervisory design has an influence on improved safety status and behavior of people. 
4.6. Correlation analysis of supervisory practices and level of maritime accidents and incidents in territorial waters

Correlational analysis using Pearson's Product Moment technique was done to determine the relationship between supervisory practices and maritime accidents and incidents in territorial waters. The results were presented in Table 4.4.

Table 4.4: Correlation matrix for supervisory practices and level of maritime accidents and incidents in territorial waters

\begin{tabular}{|c|c|c|c|c|c|}
\hline \multicolumn{6}{|c|}{ Level of maritime accidents and incidents } \\
\hline \multicolumn{3}{|c|}{$\begin{array}{l}\text { Pearson } \\
\text { correlation }\end{array}$} & Sig (2-tailed) & \multicolumn{2}{|l|}{$\mathrm{N}$} \\
\hline \multirow{2}{*}{\multicolumn{6}{|c|}{$\begin{array}{ll}\text { Supervision practices } \quad 0.540^{*} & 0.000 \\
* \text { *Correlation is significant at the } \mathbf{0 . 0 5} \text { level }\end{array}$}} \\
\hline & & & & & \\
\hline \multicolumn{6}{|c|}{$\begin{array}{l}\text { The study findings presented in Table } 4.4 \text { on correlation analysis indicated significant positive coefficients } \\
\text { among the study variables (supervision practices } 0.540 \text {, p-values of } 0.000 \text { ). The independent variable had a } \\
\text { significant positive correlation that was significant on level of maritime accidents and incidents. This implied } \\
\text { that supervision practices had a positive influence on the level of maritime accidents and incidents. } \\
\text { Table 4.5: Regression results concerning influence of supervision practices on level of maritime accidents } \\
\text { and incidents in territorial waters. }\end{array}$} \\
\hline Model & $\mathbf{R}$ & R Square & Std Error & t & P-Value \\
\hline \multirow[t]{3}{*}{ Constant } & 0.885 & 0.783 & 0.2640 & 36.234 & 0.000 \\
\hline & $\begin{array}{l}\text { Unstandar } \\
\text { Coefficie }\end{array}$ & dized & $\begin{array}{l}\text { Standardized } \\
\text { Coefficients }\end{array}$ & $\mathbf{t}$ & P-Value \\
\hline & B & tdd Error & Beta & & \\
\hline Constant & 1.905 & 0.296 & & 8.558 & 0.000 \\
\hline $\begin{array}{l}\text { Supervision } \\
\text { practices }\end{array}$ & 0.394 & 0.066 & 0.531 & 8.970 & 0.000 \\
\hline
\end{tabular}

a. Predictors: (Constant), supervision practices

b. Dependent Variable: level of maritime accidents and incidents in territorial waters

Beta coefficients indicated that supervision practices had a strong positive influence of (0.531). Implying that supervision practices had a positive and significant relationship with level of maritime accidents and incidents in territorial waters. From the statistical analysis in Table 4.5 supervision practices can explain $78.3 \%$ of variation in maritime incidents and accidents in territorial waters, Kenya. The regression model is represented as follows;

$$
\begin{aligned}
& \mathrm{Y}=1.905+0.531 \mathrm{X}+\mathrm{e} \\
& \text { Where; } \\
& \mathrm{Y}=\text { Level of maritime accidents and incidents } \\
& \mathrm{X}=\text { Supervision practices } \\
& \mathrm{e}=\text { Error term }
\end{aligned}
$$

The findings by Fatoumatta (2015) established that institutions with a well-organized reporting and supervisory channels were associated with lesser incidents resulting from human and mechanical errors. The Idiri (2012) also found that proper supervisory mechanisms reduces chances of repeat accidents. This is especially possible if an organization establishes the cause of accidents and rectify or eliminate the contributors.

\subsection{Conclusions}

Level of maritime accidents and incidents in territorial waters was identified in the current study as the dependent variable. The research findings showed that $r$ was equal to 0.885 indicating that supervision practices had a strong influence on level of maritime accidents and incidents of territorial waters. The value of $\mathrm{r}^{2}$ was 0.783 , indicating the four variables explained $78.3 \%$ of the variation in the level of maritime accidents and incidents of territorial waters, Mombasa County, Kenya. The $t$-values were statistically significant $(t=8.970, p=0.000<0.05$ suggesting that supervision practices had a statistically significant influence on level of maritime accidents and incidents of territorial waters.

\subsection{Recommendations}

This study has implication to government agencies and especially Ministry of Transport and Infrastructure in which the KFS is placed. Policy makers should ensure that managers would adapt right supervisory practices to ensure the level of maritime accidents and incidents have decreased. The findings from this study provided an indication that the change in level of maritime accidents was influenced by proper supervisory practices. The facility managers should emphasize the need of continuous checks at all levels that will monitor employees' 
efficiency in handling of vessels in order to reduce incidents and accidents and achieve the mandate and strategic objectives of KFS. The facility managers could apply the findings of the study on the areas of selection of recruitment of staff, involvement of key maritime stakeholders and alignment of the entire system towards enhancing safety in territorial waters. Given the study focused in ferry services in Mombasa County, Kenya, it was recommended that similar studies be replicated covering other counties or countries in the East African region and compare their result to the current study. Similar study could be replicated in other developing countries that are undergoing similar maritime challenges.

\section{REFERENCES}

Abuyeka, A. (2014). Factors influencing institutional safety communication: Empirical evidence. Maritime Policy and Management, 29(6), 207-214.

Akinyi, O. (2009). Institutional training vs change. Meta-analysis of studies made in 16 countries. Accident Analysis \& Prevention, 27(3), 511-524.

Balmat, J. F., Lafont, F., Maifret, R., \& Pessel, N. (2009). Maritime risk assessment (MARISA), a fuzzy approach to define individual ship risk factor. Ocean engineering, 36(16), 1278-1286.

Bergantino, A. S., \& Marlow, P. (2014). Factors influencing the choice of flag: Empirical evidence. Maritime Policy and Management, 25(2), 157-174.

Buzancic, P. B., \& Parunov, J. (2016). Review of statistical data on ship accidents. Maritime Technology and Engineering, 809-814.

Coast Development Authority (CDA). (2015). Integrated coastal area management: Kenya coastal management programme annual work plan, Mombasa, Kenya.

Cooper, D. R., \& Schndler, P. S. (Eds.). (2008). Business research methods. New York: McGraw-Hill.

Eide, M. S., Endresen, O. Brett, P. O., Ervik, J. L., \& Roang, K. (2007). Intelligent ship traffic monitoring for oil spill prevention: Risk based decision support building on AIS. Marine pollution bulletin, 54(2), 145-148.

Fatoumatta, C. (2015). A study on marine accident causation models employed by marine casualty investigators.

Galic, S., Lucik, Z., \& Skoko, I. (2014). The role and importance of safety in maritime transportation. IMSC $6^{\text {th }}$ International Maritime Science Conference.

Glaesel, H. (2008). State and local resistance to the expansion of two environmentally harmful marine fishing techniques in Kenya. Society and Natural Resources, 13, 321-338.

Hamand, H. B. (2017). Maritime Terrorism: Why the East African community is the next potential target of maritime terrorism. Research on Humanities \& Social Sciences, 6(6), 20-26.

Hetherington, C., Flin, R., \& Mearns, K. (2006). Safety in shipping: The human element. Journal of safety research, 37(4), 401-411.

Holling, C. S. (2016). Adaptive environmental assessment and management: Current progress and prospects for the approach: Summary report of the First policy seminar 18-21 June. International Institute for Applies Systems Analysis, Laxenberg, Austria.

Idiri, L. (2012). Automatic identification system of maritime accident risk using rule-based reasoning. In System of Systems Engineering (SoSE), $20127^{\text {th }}$ International Conference 125-130.

IMO. (1997). Code for the Investigation of Marine Casualties and Incidents. IMO Document Res. A.849 (20). IMO, London.

Kenya Gazette (2009). Maritime safety and regulation.

Kim, H. T., Na, S., \& Ha, W. H. (2013). A case study of marine accident investigation and analysis with focus on human error. Journal of the Ergonomics Society of Korea, 30(1), 137-150.

KMA. (2017). Kenya Maritime Search and Rescue Plan. Retrieved from http://kma.go.ke/index.php/safetysecurity-a-environment/search-a-rescue

Lin, C. T. \& Wang, S. M. (2017). Engineering officers of national vessels in Taiwan. Information and Management Sciences, 11(4), 13-30.

Malmo, E., \& Dalaklis, D. (2017). Improving maritime situational awareness: Establishing a maritime safety and security NMIOTC Conference Chania, Greece.

Metalden, B. M., \& Upnes, A. K. (2017). Maritime safety and information and communications technologies: Challenges and opportunities. WMU Journal of Maritime Affairs, 13(1), 3-25.

Merchant Shipping Act (2009).

Mugenda, O., \& Mugenda, A. (2003). Research methods: ACT

Onsongo, S. K. (2017). Analysis of the domestic passenger ferry safety in Kenya (2017). World Maritime University Dissertations. 552.

Peters, J. (2017). The international ocean transport industry in crisis. The World Bank, Washington, DC, 41.

Pietrzykowski, Z. (2010). Maritime intelligent transport systems. International Conference on Transport Systems Telematics (455-462).

Smith, J. P. (2009). Safety climate on vessel accidents in deep seas context. Accident Analysis \& 
Prevention, 40(2), 594-601.

Tenold, S. (2018). A most convenient flag - the basis for the expansion of the Singapore Fleet. 1969-82. Maritime Policy and Management, 30(3), 255- 268.

Theresa, W. (2000). Ship accidents, risk assessment and safety standards, critical literature review. Maritime Technology and Engineering, 6, 98-114.

Wang, T. \& Feng, M. (2016). Financial performance evaluations of the public shipping companies in Taiwan. Traffic and Transportation, 19, 1-13

Wolf, A. Killa, F., Wilson, F., \& Fregah, H. (2007). Human error and marine accident investigation. Journal of the Ergonomics Society of Korea, 30(1), 137-150. 